\title{
Social Capital and Dynamic Capability Driving Competitive Advantage: The Moderating Role of Corporate Governance
}

\author{
Yih-Chang Ou ${ }^{1}$, Li-Chang $\mathrm{Hsu}^{1} \&$ Shang-Ling $\mathrm{Ou}^{2}$ \\ ${ }^{1}$ Department of Finance, Ling Tung University, Taiwan, R.O.C. \\ ${ }^{2}$ Department of Agronomy, National Chung Hsing University, Taiwan, R.O.C. \\ Correspondence: Shang-Ling Ou, 250 KuoKuang Rd., Taichung, 40227, Taiwan, R.O.C. Tel: 886-4-2284-0777 \\ Ext. 203. E-mail: slou@dragon.nchu.edu.tw
}

Received: February 11, 2015

Accepted: March 4, 2015

Online Published: April 25, 2015

doi:10.5539/ibr.v8n5p1

URL: http://dx.doi.org/10.5539/ibr.v8n5p1

\begin{abstract}
In the search for factors that drive competitive advantage, this paper develops a framework that links a firm's capabilities and resources to its competitive advantage. The notion of governance is used as a supervisory mechanism for an organization's sources of competitive advantage. In light of empirical advancement, this paper examines panel data of 250 high technology firms from 2001 to 2009. The findings demonstrate that the impact of dynamic capability for production on competitive advantage is positive. However, the dynamic capability for R\&D does not have a significant effect. Moreover, the social capital to build network relationships with a firm's partners emerges as essential in achieving competitive advantage. We also find that governance moderates the impact of dynamic capability and social capital on competitive advantage. The findings of this study have important management implications. Limitations of the study are considered and future research directions are identified.
\end{abstract}

Keywords: social capital, dynamic capability, competitive advantage, corporate governance

\section{Introduction}

Strategic managers have recently focused on dynamic capability as a concept that promises to answer the question of how some organization appear to better secure competitive advantage in a dynamic market. From the knowledge-based view (KBV), the primary goal of the firm is the application of existing knowledge to the production of goods and services (Grant, 1996). Knowledge and skills give a firm competitive advantage, because it is through this set of knowledge and skills that a firm is able to innovate new products and processes, or improve existing ones more efficiently and or effectively (Nonaka \& Takeuchi, 1995; Tsai, 2005). If a firm can reconfigure its knowledge to seize newly emerging market opportunities faster than its rivals, it can develop stronger competitiveness than its rivals (Menguc \& Auh, 2006).

Our study addresses three shortcomings in the extant literature. First of all, success in today's fiercely competitive commercial environment requires an organization to pursue a coherent strategy to articulate its plans to develop, acquire, and deploy resources to achieve superior competitive advantage (Pillai, 2006). Though some progress has been made in exploring the determinants of competitive advantage (Kraatz, 1998), there is limited empirical evidence on the impact of dynamic capabilities and social capital on a firm's competitive advantage. One limitation is that most previous research has focused on a single relationship at a time. The lack of thorough consideration on the nature of the relationships between dynamic capabilities, social capital, and competitive advantage may limit the strategic value of these research findings.

The second shortcoming this study speaks to concerns the consideration that various strategies exist for gaining competitive advantage over the competition, such as the classic quality (Liker \& Wu, 2000), cost (Dawson, 2001), and innovation strategies (Von Hippel \& Katz, 2002). It is, however, necessary that the appropriate competitive advantage be examined according to social capital based on a network relationship perspective. This raises the issue of the likely direction of resource dependence theory; a firm's critical resources may extend beyond firm boundaries. There is an emerging view of the firm that sees organizations with "particular capabilities for creating and sharing knowledge that gives them distinctive advantages over other institutional arrangements" (Nahapiet \& Ghoshal, 1998). This view is firmly tied to the concept of social capital, which 
suggests that firms engage in various types of relationships with external partners to allow them access to various types of external resources (Kianto \& Waajakkoski, 2010).

Thirdly, according to agency theory, it is logical and necessary to first understand the effects of corporate governance mechanism on the competitive advantage. This study suggests that corporate governance serves as a moderator of the respective impact of dynamic capability and social capital on competitive advantage. This proposition is consistent with the literature (Makadok, 2003). Specifically, Makadok (2003) states that "future research on the genesis of competitive advantage should examine the corporate governance issue along with, not apart from, resource-based issue". A moderator is available that interacts with predictors (e.g., dynamic capabilities and social capital) and is related to a criterion variable (e.g., competitive advantage) (Sharma et al., 1981). If this moderating relationship is empirically supported, the effects of dynamic capability and social capital on competitiveness can be better understood.

Consistent with such a call, the current paper acknowledges the foundational role of dynamic capability and social capital in affecting firm-level competitive advantage and it views the supervisory mechanism of corporate governance as a moderating factor on these relationships. The results thus fill a void in the literature by developing an integrative theoretical model that sheds light on competitive advantage. To summarize, competitive advantages cannot be fully understood without a logical combination of these three research perspectives: (1) dynamic capability theory (for the firm's capabilities available for long-term deployment by its managers) (Wang \& Ahmed, 2007), (2) social capital theory (for the firm's external network relationship enhanced by top mangers' interlocking) (Westerlund \& Svahn, 2008), and (3) agency theory (for the firm and its manager's motivations) (Eisenhardt, 1989).

This paper is organized as follows. First, we review the literature related to the constructs of the proposal model. We aim to contribute to the field of strategic decision making by providing a directed application of capability and resources dimensions and by examining the moderating of corporate governance at the firm-level competitive advantage. Second, we develop a series of hypotheses which constitute an integrative theoretical framework that offers a richer and more formalized account of the relationships than has been provided in the literature to date. We next take the high technology industry as an empirical example by using the panel data. Finally, we conclude with a discussion on some implications, limitations, and directions for future research derived from the findings of this paper.

\section{Theoretical Background and Hypotheses Development}

In the following figure we present the conceptual framework discussed above. The conceptual model focuses on the knowledge exchange between the dynamic capabilities (internal knowledge resources) and its social capital (external knowledge resources), for performance in the form of competitive advantage, which is affected by governance mechanisms. Important aspects in this model are that dynamic capabilities and their network develop that they are able to gain competitive advantage.

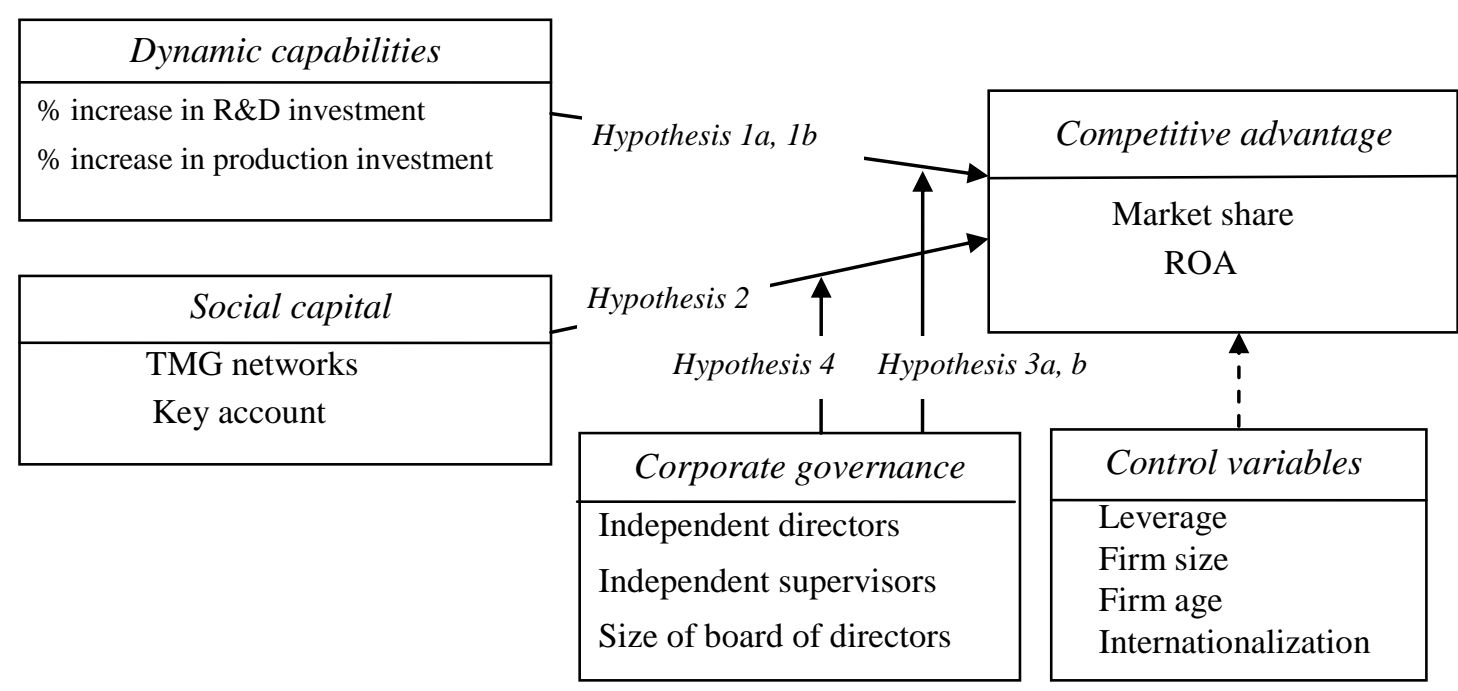

Figure 1. Proposed model 
The initial concept of "competitive advantage" was defined by Selznick (1957) and Ansoff (1965) as enterprises will develop more product market scope and better competitive position than those of competitors. Porter (1991) argues that a firm's competitive advantage is a function of not only the firm's operating environment but also its internal capabilities. From the RBV viewpoint, a competitive advantage should be difficult to imitate or substitute (Barney, 1991); and the strategic manager will much emphasize resource allocation, core capabilities, and unique technology to achieve competitive advantage over competing firms (Hill \& Jones, 1995). Moreover Marti (2001) suggests that core capabilities and network relationships are the most important drivers of sustainable competitive advantage. Lippman and Rumelt (1982) argued that firms sustain competitive advantage when their competencies possess strong causal ambiguity because competitors are less likely to identify or understand such competencies well enough to imitate them. Another recently approach emphasizes building competitive advantage through "dynamic capabilities" stressing on exploiting existing internal and external firm specific competencies and new ones to address changing environments. Based on the previous literature, we define competitive advantage as a capability or resource that is difficult to imitate and valuable in helping the firm to obtain its organizational strategic objectives

There are varying definitions of dynamic capability in the literature (Ambrosini et al., 2009; Stahle \& Bounfour, 2008; Teece, 2007). Teece et al. (1997) define dynamic capability as the key role of strategic management in appropriately adapting, integrating, and reconfiguring internal and external organizational skills, resources, and functional competences to match the requirements of a changing environment. Furthermore, Eisenhardt and Martin (2000) define dynamic capability as "the firm's ability to integrate, build, and reconfigure internal and external competencies to address rapidly changing environments." Confounding the situation is the fact that a significant number of studies pertinent to dynamic capability do not clarify their interpretation of the concept (e.g., Winter, 2003). Though the various definitions of dynamic capability proposed by different authors are confounding, they provide critical insights into the way dynamic capability have emerged form from the mainstream of strategic management literature. We herein define dynamic capability as a firm's competence which allows the firm to integrate and create its new product and processes and is able to cope with environmental change (Hsu \& Wang, 2012). In line with this definition, we infer from this fact that what may have dynamic capabilities in R\&D capability (Thornhill, 2006; Wang \& Hsu, 2010) and production capability (Katsikeas, 1994).

Given the general picture of R\&D activities for innovation capabilities, however, the accumulated investment in R\&D compared to investing at a given point in time can be especially important if a firm's strategic intent is to develop distinctive innovation capabilities. Absorptive capability was initially proposed by Cohen and Levinthal in 1990 (Cohen \& Levinthal, 1990), referring to a firm's ability to identify, assimilate, and exploit knowledge from external sources; in addition, prior related knowledge plays a key role in its innovative activities. This prior knowledge contains the past abilities or even latest technological or scientific advance. Thus, maintaining continuously investment in R\&D processes can foster the firm's dynamic capability and better create competitive advantage (Tidd et al., 2001). In sum, dynamic capability for R\&D activity has a dual role, firms invest in R\&D over time not only in order to innovate, but also to develop and maintain their broader capabilities to use knowledge. One of the reasons that firms engage in $R \& D$ is to develop what Cohen and Levinthal call "absorptive capability." In that sense, the dynamic capability for R\&D activities contributes to a firm's competitive advantage.

In a dynamic environment, the firm that invests resources more productively can achieve superior competitive advantage, despite the high costs associated with these activities. Long-term investment of production capabilities can also increase the likelihood of having a successful product at any given time period (Ahuja et al., 2008). Over time, this stream of successes through accumulated productive resources assures competitive advantage, which generates the financial profits needed to support the firm's dynamic capability for production efforts (Reichstein \& Salter, 2006). In other words, the competitive advantage from any single new product introduction in a competitive environment may be short-lived because of rapid imitation and short product life cycle (Moustaghfir, 2009). A lack of consistent investment on production capability can also undermine the firm's bargaining power with their partner that sometimes helps maintain competitive advantage (Geels, 2004). Since a long-term production capability investment is necessary to capitalize on the changes and achieve competitive advantage, therefore:

Hypothesis 1 . The dynamic capability for $R \& D$ has a positive impact on competitive advantage.

Hypothesis $1 b$. The dynamic capability for production has a positive impact on competitive advantage.

Over the past two decades, social capital has already received much attention from a wide range of disciplines, in 
particular sociology (Portes, 1998), organization theory (Burt, 1997), and network studies (Leana \& Van Buren, 1999). Burt (1997) conceptualized social capital as "a set of social resources embedded in relationships". Nahapiet and Ghoshal (1998) argued that social capital arises from the positive interaction that occurs between individuals and a network. Moreover, some organizational scholars espoused a broader dimension of social capital from the viewpoints of social relationships, norms, and values (Boytsun et al., 2011; Kianto \& Waajakoski, 2010; Tsai \& Ghoshal, 1998). Lesser (2000) proposed that networks are an important source of social capital. Social capital is inherent in personal relationship ties and interpersonal interactions (Roussel \& Deltour, 2012), together with the shared values that are associated with these relationships and interactions.

This study is concerned with the role of social capital in influencing a firm's competition advantage. We define social capital as the implicit and tangible set of resources available to enhance the organization's competitive advantage by virtue of networks relationships. Social exchange theory (Blau, 1964) supports a wide rationale for social capital since it considers the mutual values potential of inter-organizational exchange, concentrating on the relationship rather than the transaction. Relationships are embedded in a social structure (Granovetter, 1985), and time complex personal and organizational structures evolve between firms. Some studies argue that social relationships (Scupola et al., 2010) and managers' personal ties play a crucial role in developing these network relationships (Carmona-Lavado et al., 2010). Personal ties are important in multiple ways, such as providing access to external resources that could be used to gain competitive advantage (Moran, 2005). Through social networks, managers have opportunities to establish partner relationships and to detect future developments in a dynamic market. Clearly, social capital requires both the social structure and the ability to mobilize resources through that structure. It is jointly owned by the parties in the relationship and cannot be appropriated by any single individual (Burt, 1992).

Long-term relationships are beneficial to many interfirm interactions (Dyer, 2000), though the difficulties in building such a relational exchange start as early as the initiation phase. A firm's critical resources may span firm boundaries and may be embedded in interfirm processes (Smith et al., 1995). It is easy for firms to switch trading partners with non-specific investments in establishing network relationships for obtaining relation-specific social capital when they have crafted competitive advantage (Dyer \& Singh, 1998). Social capital enables linking to external actors that can help mobile resources across firm boundaries (Kim, 2007; Luthans \& Youssef, 2004). In order to obtain competitive advantage, firms need to utilize external resources effectively through their firm's network relationships (Elfring \& Hulsink, 2003). We posit that social capital is fundamental to competitive strategic choice. Therefore,

Hypothesis 2. Social capital has a positive impact on competitive advantage.

Corporate governance is a topic which has recently captured an increasing interest in academic research, though corporate dynamic strategies has not been considered adequately, and much of the discussion about corporate governance falls into the field of finance (Dalton et al., 2003). Financial analysis is focused on the economic aspects of corporate governance, with less attention to its relationship with competitive strategy. In this section, corporate governance can be described as a process where shareholders develop specific interests in the company policy, and the management of the company responds in some way to these shareholder demands by adopting a certain corporate policy to meet their interests. Therefore, we define corporate governance as the system by which corporations are governed and monitored by shareholders (Premuroso \& Bhattacharya, 2007).

According to the "motivation-capability" logic employed by researchers in competitive dynamics (Smith et al., 2001), two drivers influence a firm's competitive strategies: a firm's motivation to engage in competitive action and its capability to do so (e.g., R\&D capability and production capability). The management literature suggests that the board of directors often plays a substantial role in firm's strategic decision-making (Judge \& Zeithaml, 1992). The corporate governance mechanism can be viewed as having various elements that can affect a firm's motivation and capability to undertake competitive actions.

We may expect corporate governance to play a moderating role when connecting dynamic capability and strategic opportunities, and eventually competitive advantage (Hutchinson \& Gul, 2004). Spending on production process is capitalized in the accounts, and then not subtracted from profit. The same is true of some elements of R\&D, depending on the accounting regime; and even if not, the firm is free to publish its financial figures. Thus decision-makers may think that unwise of an investment of a sort may be obviously risky. The least visible are lasting investments within $\mathrm{R} \& \mathrm{D}$ and productions; whose value is very difficult to show to stakeholders without detailed knowledge of the firm (Connolly \& Hirschey, 2005; Lantz \& Sahut, 2005). This can result in serious under-investment in $R \& D$ and production, and/or an inefficient competitive strategy. Because the true value of $R \& D$ is difficult for outside investors to realize (Labie, 2001; Vesala, 2007), managers 
under takeover pressures may increase the current profit at the expense of long-term growth by cutting R\&D investment. Meanwhile, close monitoring by shareholders of the managers to behave in the investors' interests is necessary. Since shareholders generally have a strong incentive to monitor the managers, they may encourage value-enhancing $R \& D$. In such circumstances we can see an advantage in corporate governance with monitoring on the managers' decision-making to maximize total return to all stakeholders. The above argument on the link between dynamic capability and competitive advantage indicates a critical intermediate variable: corporate governance.

It is reasonable to expect that effective corporate governance should help the firm move toward undertaking optimal strategic actions for achieving sustainable competitive advantage (Hosono et al., 2004). Particularly, according to agency theory, as decision makers of the firm, managers have their own economic self-interests that may be in conflict with those of the stakeholders. If corporate governance remedies that $R \& D$ and production resources are ineffectively deployed, we should anticipate optimal competitive strategy decisions made by capable managers, given strategy opportunities based on firm's favorable resource deployment. Corporate governance should contribute to the building of firm competitiveness through the efficient allocation of resources (Smith et al., 2005). Therefore, corporate governance can facilitate the dynamic capability for R\&D and production toward value-maximizing deployments by reducing inefficient managerial diversions of capability. We propose:

Hypothesis 3a. Corporate governance is a positive moderator for the impact of dynamic capability for $R \& D$ on competitive advantage.

Hypothesis 3b. Corporate governance is a positive moderator for the impact of dynamic capability for production on competitive advantage.

Social capital as an important role to achieve competitive advantage has clearly focused on the interaction relationship between the internal TMG and the external resources. For instance, the role of the TMG interlocks between firms and other sectors of the economy explain how organizations bridge the gaps between different economic sectors. Thus, the ability of TMG to access external resources is viewed as depending on their relationships with external networks (Ensley et al., 2006; Palmer, 1983). Logically, the ability to gain external resources is dependent on the physical linkage of the firms (Scott, 1991). The nature of the relationships between internal TMG and these various external corporate players (i.e., the relational social capital) will be affected by the monitoring activity of the board. Where there is a norm of reciprocity and trust involved in the relationships, we would expect a board to increasingly act in the interests of the outside shareholders with whom they have these links.

Social capital considers the significance of firm-level relationships with other entities as a resource for strategic action (Sechi et al., 2011). Many scholars hold that social capital is largely oriented to information (Koka \& Prescott, 2002) or opportunities (Burt, 1992). This social capital facilitates firm-level strategic actions by increasing its awareness of competitive opportunities in various forms. Meanwhile, corporate governance targets two different but simultaneously existing mechanisms that influence a firm's social capital: (1) the board of directors to serve shareholder's interest by effectively monitoring top managers' decisions, and (2) the organizational capability to undertake competitive actions that may be enhanced by corporate governance arrangement. It is envisaged that these relationships between social capital and competitive advantage would be positively moderated by the monitoring role of corporate governance. We propose:

Hypothesis 4. Corporate governance is a positive moderator for the impact of social capital on competitive advantage.

\section{Methodology}

\subsection{Sample and Data}

The high technology industry sector is selected for this study due to their economic success and high-stakes. The search for competitive advantage in high-tech industries often leads large firms to compete in newly formed ventures. Many firms have reaped large profits after a long-term investment history in their firms' capabilities. However, this massive growth has also led to many failures and profit losses by firms that cannot maintain competitiveness. This study examines the semiconductor industry, which can be classified as a high-tech industry. The top 308 firms, ranked by company assets, were extracted from 2001 to 2009. The original observations of these firms were matched with firm-level data from the database. However, many firms did not report the type of information we sought for this study, and those with firm-level information missing from the database were eliminated from the sample. A total of 58 firms were omitted, leaving 250 semiconductor firms in our final 
sample. Main sources of data for this study were annual report of listed companies and database of Taiwan Economic Journal (TEJ).

\subsection{Variables and Measure}

\subsubsection{Dynamic Capability}

In general, dynamic capability involves a high degree of uncertainty as to the nature (McCutchen et al., 2004) and timing of output (Arrow, 1962). In prior studies, dynamic capability is empirically operationalized by qualitative approach (Helfat, 1997; Camuffo \& Volpato, 1996; Pisano, 2000; Griffith \& Harvey, 2001), and quantitative approach (Kor \& Mahoney, 2005; Hsu \& Wang, 2012; Spanos \& Lioukas, 2001). This study follows the methodology used by Hsu \& Wang (2012), who posit dynamic capability is operationalized by secondary data over time. Dynamic capability typically involves specialized long-term investment since it does not lead to instant returns. The percentage increase in respective dynamic capability for $R \& D$ and production captures the magnitude of changes in a firm's investment over time. For example, sustaining a new product development depends to some extent on the continuity in R\&D activity involved; and there may be substantial continuity in facilities, equipment, and marketing campaign, etc. even to create a new outlet. In a high-tech industry, it takes at least 3 years to convert dynamic capability for R\&D and production into a successful product (Kor \& Mahoney, 2005; Hsu \& Wang, 2012). Accordingly, to capture the historical dynamics in investment levels, we establish the functions to calculate the average percentage increases in two proposal indexes of dynamic capability during period $t, t-1$ and $t-2$. We created a composite measure of DC based on the two specific capabilities (R\&D capability and production capability).

\subsubsection{Social Capital}

The measurement of the social capital can be readily assessed using standard network analysis. This could include an examination of TMG interlocks between firms to measure the formal business linkages of a firm, and may be extended to include common membership of social. In this study, we employ the TMG networks and key account as the proxy of social capital. This operationalization is reinforced by social network theory (Silva et al., 2006), which suggests that social capital accrues from the ties and the overall structure. Therefore, it is necessary to measure the number and attributes of outside firms with which CEOs share TMG linkage.

Key account is another measure of social capital. According to the $80 / 20$ principle, $20 \%$ of key account sales account for $80 \%$ of company sales. As stated by Piercy and Lane (2006), the clients of an extremely high share of their sales. As a consequence, firms dedicate most of their resources to their key accounts (Homburg et al., 2002; Workman et al., 2003). A core assumption in the key account literature is that firms are willing to increase their input to important customers because they hope to enhance the relationships (e.g. Ivens \& Pardo, 2007). The ratio of $5 \%$ of key account sales divided by the total sales represents a proxy of the customer relationship measure.

We considered these two variables when determining social capital, on order to obtain a full picture of all the interlocks companies have, both with inside and outside companies. However, for the empirical analysis we restrict the variables to measure, as companies may have different meanings for justifying the social capital, and some of the variables used in the multivariate analysis cannot be interpreted in the same way of inside and outside companies. Pooling both TMG linkage and key account could appropriate our study.

\subsubsection{Competitive Advantage}

Various studies have sought to measure the competitive capabilities of successful firms, including lowest cost (Roth \& Morrison, 1992), higher quality (Chandler \& Hanks, 1994), and competitive privacy (Katsikeas, 1994). Although these have been examined in the literature, researchers and managers are interested in the relation between strategic actions that a firm takes and its performance relative to competitors (Rumelt et al., 1991). Firms that are more competitive due to their dynamic capability and social networks relationship strategy will enjoy superior market share over their rivals (Bharadwaj, 2000). Hence, the traditional market share is most likely to capture the firm's competitive advantage because performance outcomes of competitive capability are usually measured in terms of market share (Day \& Wensley, 1988). In prior studies, most scholars use an accounting-based index such as return on asset (ROA), return on equity (ROE), or return on sales (ROS) (Hitt et al., 1997; Tallman \& Li, 1996) as a measure of management effectiveness (Geringer et al., 2000; Robins \& Wiersema, 1995). We employed ROA as another measure of competitive advantage.

\subsubsection{Corporate Governance}

Basically, an indicator should be the ideal mechanism by which the interests of shareholders are represented. However, the boards of directors have largely failed to fulfill this purpose because the selection of directors has 
been determined by the CEO (Monks \& Minow, 1995). Instead, a board with independent directors is more likely to behave in the interests of all shareholders than are dominated by directors close to the CEO. Other indicators of corporate governance are deemed as critical by academic research including board committees (Aaboen et al., 2006; Hill \& Jones, 1995; Jackling \& Johl, 2009), independent supervisors (Agrawal \& Knoeber, 1996; Haniffa \& Cooke, 2005; Chen et al., 2007; Liu \& Yang, 2008), inside boards of directors (Core et al., 1999), and the size of board of directors (Jackling \& Johl, 2009; Kiel \& Nicholson, 2003; Peng \& Fang, 2010). Therefore, we operationalized the corporate governance as the size of board of directors, the independent directors, and independent supervisors.

\subsubsection{Control Variables}

We rely on previous empirical studies of knowledge management motives for selection of other control variables used include firm size, firm age, leverage, and internationalization. The majority of studies in the competitive advantage (including Auh \& Menguc, 2005; Setia-Atmaja, 2009; Singh \& Gaur, 2009) control for the size of firm, invariably finding a significant positive correlation between firm size and competitive advantage. Thus, we use the natural logarithm of total capital (Segars \& Grover, 1995) to proxy for firm size. We controlled for firm age, which knowledge scholars generally view younger high-tech firms might have pursued more innovations than older firms (Setia-Atmaja, 2009). Singh and Gaur (2009) also controlled for age because they predicted that knowledge creation and diffusion was 'inherently evolutionary in nature' and would thus be influenced by a firm' age. Age was measured by the number of years the firms had been in existence. The variable leverage, representing the firm's debt to equity ratio, controls for any firm value effects due to any differences in the debt structures of the firms. The indicator of financial resources is proxied by the leverage which is measured by long-term debt over total assets. Following Bartlett and Ghoshal (1989), Shoham (1996), we used a measure of export intensity as the index of internationalization. This seems to be a good relative indicator, and has been widely used. The operational definition of internationalization is export intensity $=$ (export sales/total sales) (Geringer et al., 2000). Table 1 shows the operationalization, indicators, and sources of all the constructs in proposed model.

Table 1. Definitions of independent variables

\begin{tabular}{|c|c|c|c|}
\hline Constructs & Variables & Definition & Adapted from \\
\hline \multirow[t]{2}{*}{$\begin{array}{l}\text { Competitive } \\
\text { advantage }(\mathrm{CA})\end{array}$} & Market share & Firm sales/Market sales & $\begin{array}{l}\text { Narasimhan \& Nair, 2005; Strikwerda, 2007; } \\
\text { Wang \& Hsu, } 2010\end{array}$ \\
\hline & ROA: Return on asset & Net profit before taxes /Total assets & $\begin{array}{l}\text { Dehning \& Stratopoulos, 2003; Narasimhan } \\
\text { Nair, 2005; Nustini, } 2006\end{array}$ \\
\hline \multirow{2}{*}{$\begin{array}{l}\text { Dynamic } \\
\text { capability (DC) }\end{array}$} & RDI: R\&D capability & $\%$ increase in R\&D investment & Kor \& Mahoney, 2005; Wang \& Hsu, 2010 \\
\hline & PDI: Production capability & $\%$ increase in production investment & Wang \& Hsu, 2010 \\
\hline \multirow[t]{2}{*}{$\begin{array}{l}\text { Social capital } \\
\text { (SC) }\end{array}$} & TMG network & $\begin{array}{l}\text { The number and attributes of outside } \\
\text { firms with which CEOs share TMG } \\
\text { linkage }\end{array}$ & $\begin{array}{l}\text { Athanassiou et al., 2002; Collins \& Clark, 2003; } \\
\text { Kim \& Cannella, 2008; Shipilov \& Danis, } 2006\end{array}$ \\
\hline & Key account & $\begin{array}{l}\text { The ratio of } 5 \% \text { of key account sales } \\
\text { divided by the total sales }\end{array}$ & Hsu \& Wang, 2012; Van Buren, 1999 \\
\hline \multirow{3}{*}{$\begin{array}{l}\text { Corporate } \\
\text { governance } \\
\text { (Gov) }\end{array}$} & Independent directors & $\begin{array}{l}\text { The total number of independent } \\
\text { directors on a company's board }\end{array}$ & $\begin{array}{l}\text { Cerbioni \& Parbonetti, 2007; Liu \& Yang, 2008; } \\
\text { Wang \& Hsu, } 2010\end{array}$ \\
\hline & Independent supervisors & $\begin{array}{l}\text { The total number of independent } \\
\text { supervisors on a company's board }\end{array}$ & $\begin{array}{l}\text { Agrawal \& Knoeber, 1996; Haniffa \& Cooke, } \\
\text { 2005; Liu \& Yang, } 2008\end{array}$ \\
\hline & Size of board of directors & $\begin{array}{l}\text { The total number of directors on a } \\
\text { company's board }\end{array}$ & $\begin{array}{l}\text { Cerbioni \& Parbonetti, 2007; Kumar \& Singh, } \\
\text { 2012; Peng \& Fang, } 2010\end{array}$ \\
\hline \multirow[t]{4}{*}{$\begin{array}{l}\text { Control } \\
\text { variables }\end{array}$} & LE: Leverage & Debt divided by total liabilities & $\begin{array}{l}\text { Kanagaretnam et al., 2011; Kumar \& Singh, } \\
\text { 2012; Wang et al., } 2008\end{array}$ \\
\hline & FS: Firm size & The natural logarithm of total capital & $\begin{array}{l}\text { Segars \& Grover, 1995; Kumar \& Singh, 2012; } \\
\text { Peng, \& Fang, } 2010\end{array}$ \\
\hline & FA: Firm age & $\begin{array}{l}\text { Number of years since first date of } \\
\text { incorporation }\end{array}$ & $\begin{array}{l}\text { Kumar \& Singh, 2012; Setia-Atmaja, 2009; } \\
\text { Singh \& Gaur, } 2009\end{array}$ \\
\hline & INT: Internationalization & Export sales/Total sales & $\begin{array}{l}\text { Husted et al., 2010; Mu et al., 2007; Wang \& } \\
\text { Hsu, } 2010\end{array}$ \\
\hline
\end{tabular}




\subsection{Model}

In testing the research hypotheses underpinning the study, hierarchical regression analysis (Sharma et al., 1981) was employed to estimate the relationships between dynamic capability and social capital (independent variables) and competitive advantage achieved (dependent variable), for testing the nature of moderating effect of corporate governance:

Model 1:

Model 2:

$$
C A_{i t}=\beta_{0}+\beta_{1} R D I_{i t}+\beta_{2} P D I_{i t}+\beta_{3} S C_{i t}+\beta_{4} G O V_{i t}+\beta_{5} L E_{i t}+\beta_{6} F S_{i t}+\beta_{7} F A_{i t}+\beta_{8} I N T_{i t}+\varepsilon_{i t}
$$

$$
\begin{gathered}
C A_{i t}=\hat{\beta}_{0}+\hat{\beta}_{1} R D I_{i t}+\hat{\beta}_{2} P D I_{i t}+\hat{\beta}_{3} S C_{i t}+\hat{\beta}_{4} G O V_{i t}+\hat{\beta}_{5} L E_{i t}+\hat{\beta}_{6} F S_{i t}+\hat{\beta}_{7} F A_{i t}+\hat{\beta}_{8} I N T_{i t} \\
+\hat{\beta}_{9}\left(R D I_{i t} * G O V_{i t}\right)+\hat{\beta}_{10}\left(P D I_{i t} * G O V_{i t}\right)+\hat{\beta}_{11}\left(S C_{i t} * G O V_{i t}\right)+\varepsilon_{i t}
\end{gathered}
$$

where, $C A$ is competitive advantage, $R D I$ is \% increase in R\&D investment, $P D I$ is \% increase in production investment, $S C$ is social capital, $G O V$ is corporate governance, $L E$ is leverage, $F S$ is firm size, $F A$ is firm age, and INT is Internationalization. $\beta_{0}$ and $\hat{\beta}_{0}$ are intercept, $\beta_{i}(i=1,2, \ldots 8)$ and $\hat{\beta}_{i}(i=1,2, \ldots 11)$ are parameter, $\varepsilon_{i t}$ is the error term of firm $(i=1,2, \ldots 250)$ in period $(t=1,2, \ldots 9)$.

To examine the relative effect of independent variables on $C A$, linear regression analysis was performed; the results of the linear regression analysis are presented in Model 1 in Table 2. In order to identify a moderator variable, it is necessary to determine whether a significant interaction is present between moderator and predicator variable. If a significant interaction is found, then the relationship of moderator to the criterion variable is determined. The hierarchical regression analysis results are presented in Model 2 in Table 2.

In testing the research hypotheses underpinning the study, hierarchical regression analysis (Sharma et al., 1981) was employed to estimate the relationships between dynamic capability and social capital (independent variables) and competitive advantage achieved (dependent variable), for testing the nature of moderating effect of corporate governance:

Given the cross-sectional and time series nature of our datasets, panel data estimation methods have the advantage that they allow us to account for some unobserved heterogeneity across firms. The econometric estimation has three steps: (1) tests of pooling data using F-test and Largrange multiple (LM) test, (2) a brief discussing of the convenience of a fixed effects model versus a random effect specification using Hausman test, and (3) presenting the regression output corresponding to the spread level equations as well as a battery of tests intended to help discern which is the best fitted regression. These results yield one particular kind of estimator (i.e., fixed effects).

\section{Results}

Table 3 provides descriptive statistics, including means and standard deviations of the variables used in the

\begin{tabular}{|c|c|c|c|c|c|c|c|c|c|c|c|c|c|c|}
\hline & Mean & S.D. & 1 & 2 & 3 & 4 & 5 & 6 & 7 & 8 & 9 & 10 & 11 & 12 \\
\hline 1. Market share & 0.020 & 0.046 & & & & & & & & & & & & \\
\hline 2. ROA & 0.082 & 0.136 & 0.103 & & & & & & & & & & & \\
\hline $\begin{array}{l}\text { 3. \% Increase in } \\
\text { R\&D investment }\end{array}$ & 0.162 & 0.381 & 0.072 & -0.034 & & & & & & & & & & \\
\hline $\begin{array}{l}\text { 4. \% Increase in } \\
\text { production } \\
\text { investment }\end{array}$ & -1.415 & $26 . .257$ & -0.084 & -0.050 & 0.001 & & & & & & & & & \\
\hline 5. TMG networks & 11.73 & 19.202 & $0.253 * *$ & 0.119 & $0.264 * *$ & 0.018 & & & & & & & & \\
\hline 6. Key account & 2.04 & 1.034 & 0.038 & 0.056 & 0.012 & $-0.174 *$ & -0.036 & & & & & & & \\
\hline $\begin{array}{l}\text { 7. Size of board of } \\
\text { directors }\end{array}$ & 10.31 & 3.018 & $0.477 * *$ & 0.116 & 0.098 & 0.010 & $0.414 * *$ & 0.022 & & & & & & \\
\hline $\begin{array}{l}\text { 8. Independent } \\
\text { directors }\end{array}$ & 6.22 & 2.082 & -0.036 & 0.067 & $-0.146^{*}$ & $-0.198 * *$ & -0.041 & -0.088 & 0.076 & & & & & \\
\hline $\begin{array}{l}\text { 9. Independent } \\
\text { supervisors }\end{array}$ & 3.86 & 1.876 & -0.023 & -0.075 & 0.097 & -0.047 & $0.160^{*}$ & -0.114 & $0.163 *$ & $0.192 * *$ & & & & \\
\hline
\end{tabular}
estimation. Pairwise correlations are also presented.

Table 2. Correlations and descriptive statistics 


\begin{tabular}{lccccccccccccccccccc}
\hline 10. Leverage & 0.301 & 0.154 & -0.115 & -0.033 & 0.095 & -0.052 & 0.018 & 0.091 & 0.082 & 0.017 & 0.043 & \\
11. Firm size & 2.72 & 0.698 & $0.595 * *$ & -0.029 & $0.209 * *$ & -0.104 & $0.499 * *$ & -0.013 & $0.544 * *$ & 0.029 & $0.319 * *$ & 0.04 & \\
12. Firm age & 14.94 & 7.586 & 0.061 & $-0.150 *$ & -0.032 & -0.063 & 0.064 & -0.039 & -0.046 & $-0.048 *$ & $0.300 * *$ & 0.036 & $0.362 * *$ & & \\
13. Export intensity & 0.504 & 2.445 & $0.303 * *$ & 0.020 & -0.025 & -0.096 & 0.127 & -0.09 & $0.147 *$ & 0.093 & -0.091 & -0.099 & $0.147 *$ & -0.024 \\
\hline
\end{tabular}

$* p<.05, * * p<.01$.

As Model 1 reveals, the variable of percentage increase in production investment is statistically significant; thus, hypothesis $1 \mathrm{~b}$ is supported (Model 1: $\beta_{2}=0.0523, \mathrm{p}<.05$ ). The results suggest that for the achievement of competitive advantage, the percentage increase for production was found to play an important role, whereas no direct influence was exerted by dynamic capability for R\&D because hypothesis $1 \mathrm{a}$ is not statistically significant (Model 1: $\beta_{1}=0.0089, \mathrm{p}>.10$ ). A second test of hypothesis is statistically significant. Thus, hypothesis 2 is supported. The evidence indicates that social capital, which developed by TMG network relationship building and maintaining customer relationship, was important to the achievement of competitive advantage. Referring to Model 2, corporate governance has a significant positive moderating effect on the respective impact of dynamic capability for $\mathrm{R} \& \mathrm{D}$ and for production on competitive advantage. Thus hypothesis $3 \mathrm{a}, \mathrm{b}$ (Model 2: $\hat{\beta}_{9}=0.0373$, $\mathrm{p}<.001$, and $\hat{\beta}_{10}=0.0432, \mathrm{p}<.001$ ) are supported. Finally, the fourth hypothesis (Model 2: $\hat{\beta}_{11}=0.0212, \mathrm{p}<.001$ ) is supported by the empirical results that show corporate governance has a significantly positive moderating effect on the competitive advantage from social capital.

Table 3. Regression analysis of proposed model

\begin{tabular}{|c|c|c|c|c|}
\hline \multirow{2}{*}{ Independent variable } & \multicolumn{2}{|c|}{ Model 1} & \multicolumn{2}{|c|}{ Model 2} \\
\hline & Coefficient & $P$-value & Coefficient & $P$-value \\
\hline \multicolumn{5}{|l|}{ Effect of social capital, dynamic capability on competitive advantage } \\
\hline$\%$ Increase in R\&D investment (Hypothesis 1a) & 0.0089 & 0.4056 & 0.0165 & 0.1492 \\
\hline$\%$ Increase in production investment (Hypothesis $1 b$ ) & $0.0523 *$ & 0.0175 & $0.0292 * * *$ & 0.0000 \\
\hline Social capital (Hypothesis 2) & $0.0129 * * *$ & 0.0000 & $0.0342 *$ & 0.0497 \\
\hline Corporate governance & $0.0469 * * *$ & 0.0000 & $0.0294 * * *$ & 0.0007 \\
\hline \multicolumn{5}{|l|}{$\begin{array}{l}\text { Moderating effect of corporate governance on social capital, dynamic } \\
\text { capability, and competitive advantage }\end{array}$} \\
\hline$\%$ Increase in $\mathrm{R} \& \mathrm{D}$ investment $\times$ corporate governance (Hypothesis $3 a$ ) & & & $0.0373^{* * *}$ & 0.0000 \\
\hline $\begin{array}{l}\% \text { Increase in production investment } \times \text { corporate governance (Hypothes } \\
3 b \text { ) }\end{array}$ & & & $0.0432 * * *$ & 0.0007 \\
\hline Social capital $\times$ corporate governance (Hypothesis 4 ) & & & $0.0212 * * *$ & 0.0000 \\
\hline Leverage & $-0.4293 * * *$ & 0.0000 & $-0.3507 * * *$ & 0.0000 \\
\hline Firm size & $0.3087 * * *$ & 0.0000 & $0.3017 * * *$ & 0.0000 \\
\hline Firm age & $-0.0157^{*}$ & 0.0214 & $-0.0358 * * *$ & 0.0001 \\
\hline Internationalization & $0.2842 * * *$ & 0.0000 & $0.2986 * * *$ & 0.0000 \\
\hline Intercept & $-0.1089 * * *$ & 0.0007 & $-0.3840 * * *$ & 0.0000 \\
\hline $\operatorname{Adj} R^{2}$ & 0.5703 & & 0.6866 & \\
\hline F test (Cross-section F Statistic) & $87.9538 * * *$ & & $112.1344^{* * *}$ & \\
\hline LM test & $1947.812 * * *$ & & $2663.599 * * *$ & \\
\hline Hausman test (Chi-sq. statistic) & $82.8883 * * *$ & & $107.4902 * * *$ & \\
\hline
\end{tabular}

$* p<.05 ; * * p<.01 ; * * * p<.001$.

\section{Discussion and Managerial Implications}

This research contributes to the literature in several ways. First, it focuses on the examination of drivers of competitive advantage, which is a vitally important but empirically neglected topic in the strategic management 
literature. Second, it develops a comprehensive framework of competitive advantage from two sources: internal capability (i.e., dynamic capability for R\&D and production) and external resources (i.e., social capital). Third, it investigates the moderating effect of corporate governance, offering valuable insight into the monitoring necessary for the implementation and management of each type of strategic alternatives. The current paper also contributes to dynamic resourced-based and competitive advantage research literature. By integrating corporate governance and competitive dynamics, two research streams that have so far been largely disconnected, the current paper advances our knowledge of the driving of firm-level competitiveness, since competitive dynamics research has not discussed agency problem explicitly.

The results suggest that there is one primary source of competitive advantage; namely, dynamic capability for production that enables a firm to efficiently manufacture goods that differentiate their quality from the competitors. This finding corroborates existing evidence from the strategy management literature (Song \& Montoya-Weiss, 2001), highlighting the importance of such capabilities in establishing a superior competitive advantage. The idiosyncratic inherence in establishing specific production capability without time-consuming investment in other capabilities appears to account for their value (Williamson, 1991). Managerial practitioners are offered a comprehensive framework that can help them identify critical sources of competitive advantage within their company. Managers are expected to excel in production technology innovation to match the achievements of their rivals, thereby overcoming a weakness in firm's discrete investment in production process, which have traditionally unflavored specific-production asset creation (Heide \& John, 1988).

Contrary to our expectations, firms' possession of dynamic capability for R\&D appears not to play an important role in achieving competitive advantage. This contradicts a widely held belief in competitive strategic field that long-term R\&D investment in high-tech industries is a driving force for a firm's success (Morikawa, 2004). The absence of significance in the relationships dynamic capability for R\&D with competitive advantage provided an important message for strategic managers. From the risk viewpoint the potential explanation that high uncertainty exists in the $R \& D$ process since managers can not precisely forecast the market demand (Hughes, 1997). This leads to less and inconsistent R\&D investment, which undermines the effect on competitive advantage (Chan et al., 1990). Therefore, decision-makers of such firms need not see their limited R\&D capabilities as inhibiting their ability to achieve and sustain a sound competitive position in which they operate.

The empirical finding on the relationships between social capital and competitive advantage is as predicted. Based on prior literature, we speculate that firms with outside social capital are more likely to sustain a relationships-enabled competitive advantage (Shipilov \& Danis, 2006). While outside social capital facilitates access to information and other resources located outside of the organization, these must ultimately be assimilated and effectively managed within the organization. Our findings convey the important implication that TMG ties help to alleviate the level of uncertainty surrounding external resource dependence. They allow firms to secure critical resources under more favorable terms. The resource dependency benefits of relationship ties ultimately extend to competitive advantage, with evidence indicating that firms with ties to other economic sectors posing the most critical relationship connections outperform their competitors without such connections.

Recalling Hypothesis 1, the dynamic capability for production has significantly positively influenced on competitive advantage; furthermore, the empirical results support the moderating effect of corporate governance on this relationship. In other words, this result refers to long-term investment in firm-specific production capability together with effective corporate governance mechanism, which was found to facilitate the achievement of competitive advantage. Possession of the associations of the efficiency implementation production capability investment and the effective monitoring production capability deployment is deemed essential in order to enable a firm's product to appreciate customers' perceptions of value and, in turn, develop products that meet customers' specific requirements better than competitors (Woodruff, 1997).

Particular attention should be given to the development and deployment of R\&D capability. Interestingly, the result of the dynamic capability for R\&D impacts on competitive advantage was not consistent with our expectations. However, the effect of corporate governance significantly positively moderates this relationship. This finding is consistent with the theory that emphasizes the monitoring role by corporate governance (Heracleous, 2001). It means R\&D activity is a risky undertaking and not necessarily significant. Risk is expected to reduce managers' willingness to invest in R\&D, since the managers' face a higher probability of failure; however, long-term R\&D activity is a driving force for economic success. Thus, corporate governance on this specific R\&D activity context was the crucial role of either promoting risk taking and developing new competencies or encouraging the development of credibility between the managers and its stakeholders. One important pragmatic implication of this finding is that the corporate governance in a dynamic system was a stimulus to create shareholder value other than a monitoring role. Without any outside impetus, a manager may 
tend to make more conservative decisions on $R \& D$ investment. Thus, a moderately successfully $R \& D$ activity is expected to have a good corporate governance mechanism.

Concerning the achievement of a differentiation advantage position, the drivers of social capital and the moderator of corporate governance are identified as relevant and particularly important. The function of the corporate governance in our model is the traditional role of the board in monitoring the internal managers and the external stakeholders (Tricker, 1994). Consistent with seminal work on agency theory (Jensen \& Meckling, 1976), one of the possible implications of this evidence implies that the general trend of a TMG was to take a passive role in strategy formation (Chitayat, 1985). In contrast, directors provide TMG with an important source of information in the formulation of strategy (Hermalin \& Weisbach, 1998). Thus, the implication of this finding may be explained that an emerging identity for a board is as a strategy developer, rather than a monitor.

\section{Limitations and Future Research}

The results reported here should be interpreted in the light of certain limitations inherent in the study. To measure our baseline construct (e.g., firm dynamic capability), we believe that research should follow recent developments in the management literature, which has effectively employed knowledge and human resource variables. To control for effects that may be caused by other factors, such as hostility and heterogeneity (Zahra \& Bogner, 1999), these control variables that have been identified in competitive dynamics research literature as being significant on firm-level competitive behavior need to be incorporated in the empirical model.

Studying firm-level dynamic capability requires a way of developing a large set of longitudinal data by each firm in the sample. However, our study may also be limited by the data we obtained. The panel data sets were made up of 250 high-tech firms within a 6 year period. Additional studies might investigate a longer period to determine whether the same relationships hold. This view is in accordance with Boer's (1999) "time lag' to the innovation process, and of more explanations of the "learning curve plateau" suggested by Carlson (1973) and Song et al. (1998).

Further, this study was conducted in a specific high technology industry; this may limit the generalizability of our conclusion and implication, Sutton (1996) has tried to revive cross-industry analysis with an approach that uses a mixture of "watered-down" game theory and empirical data. Testing the external validity of these findings would necessitate the design and implementation of replication studies in other economic sectors, not only from the high-tech industry but also from newly industries such as biotechnology and knowledge-based information industry. Further studies will help us understand exactly what and how the drivers affect competitive capability. Nonetheless, given the scarcity of empirical literature on this important issue, we hope this study will give academics and practitioners a good starting point to discuss desirable structures for the promotion of competitive capability.

\section{Acknowledgements}

The authors would like to thank the Ministry of Science and Technology of the Republic of China, Taiwan for financially supporting this research under Contract No. NSC 98-2410-H-275-002.

\section{References}

Aaboen, L., Lindelof, P., Vonkoch, C., \& Lofsten, H. (2006). Corporate governance and performance of small $\begin{array}{lllll}\text { high-tech firms } & \text { in }\end{array}$ http://dx.doi.org/10.1016/j.technovation.2005.07.004

Agrawal, A., \& Knoeber, C. (1996). Firm performance and mechanism to control agency problem between managers and shareholders. Journal of Financial and Quantitative Analysis, 31(3), 377-397. http://dx.doi.org/10.2307/2331397

Ahuja, G., Lampert, C. M., \& Tandon, V. (2008). Moving beyond schumpeter: Management research on the determinants of technological innovation. Academy of Management Annals, 2(1), 1-98. http://dx.doi.org/10.1080/19416520802211446

Ambrosini, V., Bowman, C., \& Collier, N. (2009). Dynamic capabilities: An exploration of how firms renew their resource base. British Journal of Management, 20(1), 9-24. http://dx.doi.org/10.1111/j.1467-8551.2008.00610.x

Ansoff, H. I. (1965). Corporate strategy: An analytical approach to business policy for growth and expansion. New York: McGraw-Hill.

Arrow, K. J. (1962). Economic welfare and the allocation of resources for invention. Princeton, NJ: Princeton University Press. 
Athanassiou, N., Crittenden, W. F., Kelly, L. M., \& Márquez, P. G. (2002). Founder centrality effects on the mexican family firm's top management group: Firm culture, strategic vision and goals, and firm $\begin{array}{lllll}\text { performance. Journal of World } & \text { Business, } & 37(2), & \text { 139-150. }\end{array}$ http://dx.doi.org/10.1016/S1090-9516(02)00073-1

Auh, S., \& Menguc, B. (2005). Top management team diversity and innovativeness: The moderating role of interfunctional coordination. Industrial Marketing Management, 34(3), 249-261. http://dx.doi.org/10.1016/j.indmarman.2004.09.005

Barney, J. B. (1991). Firm resources and competitive advantage. Journal of Management, 17(1), 99-120. http://dx.doi.org/10.1177/014920639101700108

Bartlett, C. A., \& Ghoshal, S. (1989). Managing across boarders: The transnational solution. Boston: Harvard Business School Press.

Bharadwaj, A. S. (2000). A resource-based perspective on information technology capability and firm performance: An empirical investigation. MIS Quarterly, 24(1), 169-196. http://dx.doi.org/10.2307/3250983

Blau, P. (1964). Exchange and power in social life. New York: John Wiley \& Sons.

Boer, F. P. (1999). The valuation of technology: Business and financial issues in R\&D. New York: John Wiley \& Sons.

Boytsun, A., Deloof, M., \& Matthyssens, P. (2011). Social norms, social cohesion, and corporate governance. Corporate Governance, 19(1), 41-60. http://dx.doi.org/10.1111/j.1467-8683.2010.00829.x

Burt, R. S. (1992). Structural holes: The social structure of competition. MA: Harvard University Press Cambridge.

Burt, R. S. (1997). The contingent value of social capital. Administrative Science Quarterly, 42(2), 339-365. http://dx.doi.org/10.2307/2393923

Camuffo, A., \& Volpato, G. (1996). Dynamic capabilities and manufacturing automation: Organizational learning in the Italian automobile industry. Industrial and Corporate Change, 5(3), 813-832. http://dx.doi.org/10.1093/icc/5.3.813

Carlson, J. G. (1973). Cubic learning curves: Precision tool for labor estimating. Manufacturing Engineering and Management, 71(5), 22-25.

Carmona-Lavado, A., Cuevas-Rodriguez, G., \& Cabello-Medina, C. (2010). Social and organizational capital: Building the context for innovation. Industrial Marketing Management, 39(4), 681-690. http://dx.doi.org/10.1016/j.indmarman.2009.09.003

Cerbioni, F., \& Parbonetti, A. (2007). Exploring the effects of corporate governance on intellectual capital disclosure: An analysis of European biotechnology companies. European Accounting Review, 16(4), 791-826. http://dx.doi.org/10.1080/09638180701707011

Chan, S. H., Martin, J. D., \& Kensinger, J. W. (1990). Corporate research and development expenditures and share value. Journal of Financial Economics, 26(2), 255-276. http://dx.doi.org/10.1016/0304-405X(90)90005-K

Chandler, G. N., \& Hanks, S. H. (1994). Founder competence, the environment, and venture performance. Entrepreneurship: Theory and Practice, 18(3), 77-90.

Chen, K. Y., Elder, R., \& Hsieh, Y. (2007). Corporate governance and earnings management: The implication of corporate governance best-practice principles for taiwanese listed companies. Journal of Contemporary Accounting and Economics, 3(2), 73-105. http://dx.doi.org/10.1016/S1815-5669(10)70024-2

Chitayat, G. (1985). Working relationships between the chairman of the boards of directors and the CEO. Management International Review, 25(3), 65-70.

Cohen, W. M., \& Levinthal, D. A. (1990). Absorptive capacity: A new perspective on learning and innovation. Administrative Science Quarterly, 35(1), 128-152. http://dx.doi.org/10.2307/2393553

Collins, C. J., \& Clark, K. D. (2003). Strategic human resource practices, top management team social networks, and firm performance: The role of human resource practices in creating organizational competitive advantage. Academy of Management Journal, 46(6), 740-751. http://dx.doi.org/10.2307/30040665

Connolly, R. A., \& Hirschey, M. (2005). Firm size and the effect of R\&D on Tobin's Q. R\&D Management, 
35(2), 217-223. http://dx.doi.org/10.1111/j.1467-9310.2005.00384.x

Core, J. E., Holthausen, R. W., \& Larcker, D. F. (1999). Corporate governance, chief executive officer compensation, and firm performance. Journal of Financial Economics, 51(3), 371-406. http://dx.doi.org/10.1016/S0304-405X(98)00058-0

Dalton, D. R., Daily, C. M., Certo, S. Y., \& Roengpitya, R. (2003). Meta-analysis of financial performance and equity: Fusion or confusion. Academy of Management Journal, 46(1), 13-26. http://dx.doi.org/10.2307/30040673

Dawson, C. (2001). Machete time: In a cost-cutting war with Nissan, Toyota leans on suppliers. Business Week, $9,42-43$.

Day, G. S., \& Wensley, R. (1988). Assessing advantages: A framework for diagnosing competitive superiority. Journal of Marketing, 52(2), 1-20. http://dx.doi.org/10.2307/1251261

Dehning, B., \& Stratopoulos, T. (2003). Determinants of a sustainable competitive advantage: Due to an IT-enabled strategy. Journal of Strategic Information Systems, 12(1), 7-28. http://dx.doi.org/10.1016/S0963-8687(02)00035-5

Dyer, J. H., \& Singh, H. (1998). The relational view: Cooperative strategy and sources of interorganizational competitive advantage. Academy of Management Review, 23(4), 660-679. http://dx.doi.org/10.5465/AMR.1998.1255632

Dyer, J. H. (2000). Collaborative advantage: Winning through extended enterprise supplier networks. New York: Oxford University Press.

Eisenhardt, K. M. (1989). Agency theory: An assessment and review. Academy of Management Review, 14(1), 57-74. http://dx.doi.org/10.5465/AMR.1989.4279003

Eisenhardt, K. M., \& Martin, J. A. (2000). Dynamic capabilities: What are they? Strategic Management Journal, $21(10-11)$, 1105-1121. http://dx.doi.org/10.1002/1097-0266(200010/11)21:10/11\%3C1105::AID-SMJ133\%3E3.0.CO;2-E

Elfring, T., \& Hulsink, W. (2003). Network in entrepreneurship: The case of high-technology firms. Small Business Economics, 21(4), 409-422. http://dx.doi.org/10.1023/A:1026180418357

Ensley, M. D., Hmieleski, K. M., \& Pearce, C. L. (2006). The importance of vertical and shared leadership within new venture top management teams: Implications for the performance of startups. Leadership Quarterly, 17(3), 217-231. http://dx.doi.org/10.1016/j.leaqua.2006.02.002

Geels, F. W. (2004). From sectoral systems of innovation to socio-technical systems: Insights about dynamics and change from sociology and institutional theory. Research Policy, 33(6-7), 897-920. http://dx.doi.org/10.1016/j.respol.2004.01.015

Geringer, J. M., Tallman, S., \& Olsen, D. M. (2000). Product and international diversification among Japanese $\begin{array}{lllll}\text { multinational firms. Strategic Management Journal, } & 21(1), & 51-80 .\end{array}$ http://dx.doi.org/10.1002/(SICI)1097-0266(200001)21:1\%3C51::AID-SMJ77\%3E3.0.CO;2-K

Granovetter, M. (1985). Economic action and social structure: A theory of embeddedness. American Journal of Sociology, 91(3), 481-510. http://dx.doi.org/10.1086/228311

Grant, R. M. (1996). Toward a knowledge-based theory of the firm. Strategic Management Journal, 17(4), 109-122. http://dx.doi.org/10.1002/smj.4250171110

Griffith, D. A., \& Harvey, M. G. (2001). A resource perspective of global dynamic capabilities. Journal of International Business Studies, 32(3), 597-606. http://dx.doi.org/10.1057/palgrave.jibs.8490987

Haniffa, R. M., \& Cooke, T. E. (2005). The Impact of Culture and Governance on Corporate Social Reporting. $\begin{array}{lllll}\text { Journal of Accounting and Public } & \text { Policy, 24(5), }\end{array}$ http://dx.doi.org/10.1016/j.jaccpubpol.2005.06.001

Heide, J. B., \& John, G. (1988). The role of dependence balancing in safeguarding transaction-specific assets in conventional channel. Journal of Marketing, 52(1), 20-35. http://dx.doi.org/10.2307/1251683

Helfat, C. E. (1997). Know-how and asset complementarity and dynamic capability accumulation: The case of $\begin{array}{lllll}\text { R\&D. Strategic } & \text { Management } & \text { Journal, } & \text { 18(5), }\end{array}$ http://dx.doi.org/10.1002/(SICI)1097-0266(199705)18:5\%3C339::AID-SMJ883\%3E3.0.CO;2-7

Heracleous, L. (2001). What is the impact of corporate governance on organizational performance. Corporate 
Governance, 9(3), 165-173. http://dx.doi.org/10.1111/1467-8683.00244

Hermalin, B. E., \& Weisbach, M. S. (1998). Endogenously chosen boards of directors and their monitoring of the CEO. American Economic Review, 88(1), 96-118. http://dx.doi.org/10.12691/jfa-2-4-2

Hill, C. W. L., \& Jones, G. R. (1995). Strategic management theory. Boston: Houghton Mifflin.

Hitt, M., Hoskisson, R., \& Kim, H. (1997). International diversification: Effects on innovation and firm performance in product-diversified firms. Academy of Management Journal, 40(4), 767-798. http://dx.doi.org/10.2307/256948

Homburg, C., Workman, Jr. J. P., \& Jensen, O. (2002). A configurational perspective on key account management. Journal of Marketing, 66(2), 38-60. http://dx.doi.org/10.1509/jmkg.66.2.38.18471

Hosono, K., Tomiyama, M., \& Miyagawa, T. (2004). Corporate governance and research and development: Evidence from Japan. Economics of Innovation and New Technology, 13(2), 141-164. http://dx.doi.org/10.1080/10438590410001628125

Hsu, L. C., \& Wang, C. H. (2012). Clarifying the effect of intellectual capital on performance: The mediating role of dynamic capability. British Journal of Management, 23(2), 179-205. http://dx.doi.org/10.1111/j.1467-8551.2010.00718.x

Hughes, M. L. (1997). Technorisk: Who's responsible? Risk Management, 44(11), 20-28.

Husted, B. W., Allen, D. B., \& Rivera, J. E. (2010). Governance choice for strategic corporate social responsibility: Evidence from Central America. Business \& Society, 49(2), 201-215. http://dx.doi.org/10.1177/0007650308315504

Hutchinson, M., \& Gul, F. A. (2004). Investment opportunity set, corporate governance practices and firm $\begin{array}{llll}\text { performance. Journal of } & \text { Corporate }\end{array}$ http://dx.doi.org/10.1016/S0929-1199(03)00022-1

Ivens, B. S., \& Pardo, C. (2007). Are key account relationships different? Empirical results on supplier strategies and customer reactions. Industrial Marketing Management, 36(4), 470-482. http://dx.doi.org/10.1016/j.indmarman.2005.12.007

Jackling, B., \& Johl, S. (2009). Board structure and firm performance: Evidence from India's top companies. Corporate Governance, 17(4), 492-509. http://dx.doi.org/10.1111/j.1467-8683.2009.00760.x

Jensen, M. C., \& Meckling, W. H. (1976). Theory of the firm: Managerial behavior, agency costs and ownership $\begin{array}{lllll}\text { structure. Journal of } & \text { Financial 305-360. }\end{array}$ http://dx.doi.org/10.1016/0304-405X(76)90026-X

Judge, W., \& Zeithaml, C. (1992). Institutional and strategic choice perspective on board involvement in the strategic decision process. Academy of Management Journal, 35(4), 766-794. http://dx.doi.org/10.2307/256315

Kanagaretnam, K., Lim, C. Y., \& Lobo, G. J. (2011). Effects of national culture on earnings quality of banks. Journal of International Business Studies, 42(6), 853-874. http://dx.doi.org/10.1057/jibs.2011.26

Katsikeas, C. S. (1994). Export competitive advantages: The relevance of firm characteristics. International Marketing Review, 11(3), 33-53. http://dx.doi.org/10.1108/02651339410067049

Kianto, A., \& Waajakoski, J. (2010). Linking social capital to organizational growth. Knowledge Management Research \& Practice, 8(1), 4-14. http://dx.doi.org/10.1057/kmrp.2009.29

Kiel, G. C., \& Nicholson, G. J. (2003). Board composition and corporate performance: How the Australian experience informs contrasting theories of corporate governance. Corporate Governance, 11(3), 189-205. http://dx.doi.org/10.1111/1467-8683.00318

Kim, Y. (2007). The proportion and social capital of outside directors and their impacts on firm value: Evidence from Korea. Corporate Governance, 15(6), 1168-1176. http://dx.doi.org/10.1111/j.1467-8683.2007.00638.x

Kim, Y., \& Cannella, A. A. (2008). Social capital among corporate upper echelons and its impacts on executive promotion. Journal of World Business, 43(1), 85-96. http://dx.doi.org/10.1016/j.jwb.2007.10.009

Koka, B. R., \& Prescott, J. E. (2002). Strategic alliances as social capital: A multidimensional view. Strategic Management Journal, 23(9), 795-816. http://dx.doi.org/10.1002/smj.252

Kor, Y. Y., \& Mahoney, J. T. (2005). How dynamics, management, and governance of resource deployments 
influence firm level performance. Strategic Management Journal, 26(5), 489-496. http://dx.doi.org/10.1002/smj.459

Kraatz, M. S. (1998). Learning by association? Interorganizational networks and adaptation to environmental change. Academy of Management Journal, 41(6), 621-643. http://dx.doi.org/10.2307/256961

Kumar, N., \& Singh, J. P. (2012). Outside directors, corporate governance and firm performance: Empirical evidence from India. Asian Journal of Finance \& Accounting, 4(2), 39-55. http://dx.doi.org/10.5296/ajfa.v4i2.1737

Labie, M. (2001). Corporate governance in microfinance organizations: Along and winding road. Management Decision, 39(4), 296-302. http://dx.doi.org/10.1108/00251740110391466

Lantz, J. S., \& Sahut, J. M. (2005). R\&D investment and the financial performance of technological firms. International Journal of Business, 10(3), 251-270. Retrieved from http://www.craig.csufresno.edu/ijb/Volumes/Volume\%2010/V103-4.pdf

Leana, C. R., \& Van Buren, H. J. V. (1999). Organizational social capital and employment practices. Academy of Management Review, 24(3), 538-555. http://dx.doi.org/10.2307/259141

Lesser, E. L. (2000). Leveraging social capital in organizations. In E. L. Lesser (Ed.), Knowledge and Social Capital: Foundations and Applications. Boston: Butterworth-Heinemann.

Liker, J., \& Wu, Y. (2000). Japanese automakers, us suppliers and supply-chain superiority. Sloan Management Review, 42(1), 81-93. Retrieved from htttp://ftp.cs.ntust.edu.tw/hlwei/EB2007/reading/7-Japanese\%20Automakers, \%20U.S.\%20Suppliers\%20an d\%20Supply-Chain\%20Superiority.pdf

Lippman, S. A., \& Rumelt, R. P. (1982). Uncertain imitability: An analysis of interfirm differences in efficiency under competition. Bell Journal of Economics, 13(2), 418-438. http://dx.doi.org/10.2307/3003464

Liu, J. S., \& Yang, C. (2008). Corporate governance reform in Taiwan: Could the independent director system be an effective remedy? Asian Survey, 48(5), 816-838. http://dx.doi.org/10.1525/AS.2008.48.5.816

Luthans, F., \& Youssef, C. M. (2004). Human, social, and now positive psychological capital management. Organizational Dynamics, 33(2), 143-160. http://dx.doi.org/10.1016/j.orgdyn.2004.01.003

Makadok, R. (2003). Doing the right thing and knowing the right thing to do: Why the whole is greater than the sum of the parts. Strategic Management Journal, 24(10), 1043-1055. http://dx.doi.org/10.1002/smj.313

Marti, J. M. V. (2001). ICBS-intellectual capital benchmarking system. Journal of Intellectual Capital, 2(2), 148-165. http://dx.doi.org/10.1108/14691930110385937

McCutchen, Jr. W. W., Swamidass, P. M., \& Teng, B. S. (2004). R\&D risk-taking in strategic alliances: New explanations for R\&D alliances in the biopharmaceutical industry. Management International Review, 44(1), 53-67.

Menguc, B., \& Auh, S. (2006). Creating a firm-level dynamic capability through capitalizing on market orientation and innovativeness. Journal of the Academy of Marketing Science, 34(1), 63-73. http://dx.doi.org/10.1177/0092070305281090

Monks, R., \& Minow, N. (1995). Corporate governance. London: Blackwell.

Moran, P. (2005). Structural vs. relational embeddedness: Social capital and managerial performance. Strategic Management Journal, 26(12), 1129-1151. http://dx.doi.org/10.1002/smj.486

Morikawa, M. (2004). Information technology and the performance of Japanese SMEs. Small Business Economics, 23(3), 171-177. http://dx.doi.org/10.1023/B:SBEJ.0000032023.11566.4b

Moustaghfir, K. (2009). How knowledge assets lead to a sustainable competitive advantage: Are organizational capabilities a missing link? Knowledge Management Research \& Practice, 7(4), 339-355. http://dx.doi.org/10.1057/kmrp.2009.26

Mu, S. H., Gnyawali, D. R., \& Hatfield, D. E. (2007). Foreign subsidiaries learning from local environments: An $\begin{array}{lllll}\text { empirical test. Management International Review, 47(1), } & \text { 79-102. }\end{array}$ http://dx.doi.org/10.1007/s11575-007-0005-5

Nahapiet, J., \& Ghoshal, S. (1998). Social capital, intellectual capital, and the organizational advantage. Academy of Management Review, 23(2), 242-266. Retrieved from http://staffweb.hkbu.edu.hk/vwschow/lectures/ism3620/rp01.pdf 
Narasimhan, R., \& Nair, A. (2005). The antecedent role of quality, information sharing and supply chain proximity on strategic alliance formation and performance. International Journal of Production Economics, 96(3), 301-313. http://dx.doi.org/10.1016/j.ijpe.2003.06.004

Nonaka, I., \& Takeuchi, H. (1995). The knowledge-creating company. New York: Oxford University Press.

Nustini, Y. (2006). Determinants of sustainable competitive advantage due to an it-enabled strategy. Jurnal Siasat Bisnis, 11(1), 21-36.

Palmer, D. (1983). Broken ties: Interlocking directorates and intercorporate coordination. Administrative Science Quarterly, 28(1), 40-55. http://dx.doi.org/10.2307/2392384

Peng, Y. S., \& Fang, C. P. (2010). Acquisition experience, board characteristics, and acquisition behavior. Journal of Business Research, 63(5), 502-509. http://dx.doi.org/10.1016/j.jbusres.2009.04.009

Piercy, N., \& Lane, N. (2006). The underlying vulnerabilities in key account management strategies. European Management Journal, 24(2-3), 151-162. http://dx.doi.org/10.1016/j.emj.2006.03.005

Pillai, K. G. (2006). Networks and competitive advantage: A synthesis and extension. Journal of Strategic Marketing, 14(2), 129-145. http://dx.doi.org/10.1080/09652540600659756

Pisano, G. (2000). In Search of Dynamic Capabilities: The Origins of R\&D Competence in Biopharmaceuticals. In G. Dosi, R. R. Nelson, \& S. G. Winter (Eds.), The Nature and Dynamics of Organizational Capabilities. Oxford: Oxford University Press.

Porter, M. E. (1991). Towards a dynamic theory of strategy. Strategic Management Journal, 12(1), 95-117. http://dx.doi.org/10.1002/smj.4250121008

Portes, A. (1998). Social capital: Its origins and applications in modern sociology. Annual Review of Sociology, 24(1), 1-24. http://dx.doi.org/10.1146/annurev.soc.24.1.1

Premuroso, R. F., \& Bhattacharya, S. (2007). Is there a relationship between firm performance, corporate governance, and a firm's decision to form a technology committee? Corporate Governance, 15(6), 1260-1276. http://dx.doi.org/10.1111/j.1467-8683.2007.00645.x

Reichstein, T., \& Salter, A. (2006). Investigating the sources of process innovation among UK manufacturing firms. Industrial and Corporate Change, 15(4), 653-682. http://dx.doi.org/10.1093/icc/dt1014

Robins, J., \& Wiersema, M. F. (1995). A resource based approach to the multibusiness firm: Empirical analysis of portfolio interrelationships and corporate financial performance. Strategic Management Journal, 16(4), 277-299. http://dx.doi.org/10.1002/smj.4250160403

Roth, K., \& Morrison, A. J. (1992). Business-Level Competitive Strategy: A Contingency Link to $\begin{array}{lllll}\text { Internationalization, } \quad \text { Journal } & \text { Management, } & \text { 18(3), }\end{array}$ http://dx.doi.org/10.1177/014920639201800303

Roussel, C. S., \& Deltour, F. (2012). Beyond cross-functional teams: Knowledge integration during organizational projects and the role of social capital. Knowledge Management Research \& Practice, 10(2), 128-140. http://dx.doi.org/10.1057/kmrp.2011.45

Rumelt, R. P., Schendel, D., \& Teece, D. J. (1991). Strategic management and economics. Strategic Management Journal, 12(8), 5-29. http://dx.doi.org/10.1002/smj.4250121003

Scott, J. (1991). Networks of corporate power: A comparative assessment. Annual Review of Sociology, 17(1), 181-203. http://dx.doi.org/10.1146/annurev.so.17.080191.001145

Scupola, A., Steinfield, C., \& Lopez-Nicolas, C. (2010). Social capital, ICT use and company performance: Findings from the medicon valley biotech cluster. Technological Forecasting and Social Change, 77(7), 1156-1166. http://dx.doi.org/10.1016/j.techfore.2010.03.004

Sechi, G., Borri, D., De Lucia, C., \& Celmins, V. (2011). Social Capital as Knowledge Facilitator: Evidence from Latvia. Knowledge Management Research \& Practice, 9(3), 245-255. http://dx.doi.org/10.1057/kmrp.2011.17

Segars, A. H., \& Grover, V. (1995). The industry level impact of information technology: An empirical analysis $\begin{array}{llll}\text { of three } & \text { industries. } & \text { Decision 26(3), } & \text { 337-368. }\end{array}$ http://dx.doi.org/10.1111/j.1540-5915.1995.tb01432.x

Selznick, P. (1957). Leadership in administration: A sociological interpretation. New York: Harper \& Row. 
Setia-Atmaja, L. Y. (2009). Governance mechanisms and firm value: The impact of ownership concentration and dividends. Corporate Governance, 17(6), 694-709. http://dx.doi.org/10.1111/j.1467-8683.2009.00768.x

Sharma, S., Durand, R. M., \& Gur-Arie, O. (1981). Identification and analysis of moderator variables. Journal of Marketing Research, 18(3), 291-300. http://dx.doi.org/10.2307/3150970

Shipilov, A., \& Danis, W. (2006). TMG social capital, strategic choice and firm performance. European Management Journal, 24(1), 16-27. http://dx.doi.org/10.1016/j.emj.2005.12.004

Shoham, A. (1996). Marketing-mix standardization. Journal of Global Marketing, 10(2), 53-73. http://dx.doi.org/10.1300/J042v10n02_04

Silva, F., Majluf, N., \& Paredes, R. D. (2006). Family ties, interlocking directors and performance of business groups in emerging countries: The case of Chile. Journal of Business Research, 59(3), 315-321. http://dx.doi.org/10.1016/j.jbusres.2005.09.004

Singh, D. A., \& Gaur, A. S. (2009). Business group affiliation, firm governance, and firm performance: Evidence from China and India. Corporate Governance, 17(4), 411-425. http://dx.doi.org/10.1111/j.1467-8683.2009.00750.x

Smith, K. G., Carroll, S. J., \& Ashford, S. J. (1995). Intra-and interorganizational cooperation: Toward a research agenda. Academy of Management Journal, 38(1), 7-23. http://dx.doi.org/10.2307/256726

Smith, K. F., Ferrier, W. J., \& Ndofor, H. (2001). Competitive dynamics research: Critique and future directions. In M. A. Hitt, R. E. Freeman \& J. S. Harrison (Eds.), Blackwell Handbook of Strategic Management. Malden, MA: Blackwell Publishers.

Smith, A., Stirling, A., \& Berkhout, F. (2005). The governance of sustainable socio-technical transitions. Research Policy, 34(10), 1491-1510. http://dx.doi.org/10.1016/j.respol.2005.07.005

Song, X. M., Thieme, R. J., \& Xie, J. (1998). The impact of cross-functional joint involvement across product development stages: An exploratory study. Journal of Product Innovation Management, 15(4), 289-303. http://dx.doi.org/10.1016/S0737-6782(97)00108-2

Song, X. M., \& Montoya-Weiss, M. M. (2001). An examination of the effect of perceived technological uncertainty on Japanese new product development. Academy of Management Journal, 44(1), 61-80. http://dx.doi.org/10.2307/3069337

Spanos, Y. E., \& Lioukas, S. (2001). An examination into the causal logic of rent generation: Contrasting porter's competitive strategy framework and the resource-based perspective. Strategic Management Journal, 22(10), 907-934. http://dx.doi.org/10.1002/smj.174

Stahle, P., \& Bounfour, A. (2008). Understanding dynamics of intellectual capital of nations. Journal of Intellectual Capital, 9(2), 164-177. http://dx.doi.org/10.1108/14691930810870283

Strikwerda, J. (2007). Executing strategy in turbulent times: How capital markets impact corporate strategy. Assen/Zeist: Van Gorcum.

Sutton, J. (1996). Technology and market structure. European Economic Review, 40(3-5), 511-530. http://dx.doi.org/10.1016/0014-2921(95)00065-8

Tallman, S., \& Li, J. (1996). Effects of international diversity and product diversity on the performance of multinational firms. Academy of Management Journal, 39(1), 179-196. http://dx.doi.org/10.2307/256635

Teece, D. J., Pisano, G., \& Shuen, A. (1997). Dynamic capabilities and strategic management. Strategic Management Journal, $18(7), \quad 509-533$. http://dx.doi.org/10.1002/(SICI)1097-0266(199708)18:7\%3C509::AID-SMJ882\%3E3.0.CO;2-Z

Teece, D. J. (2007). Explicating dynamic capabilities: The nature and microfoundations of (sustainable) enterprise performance. Strategic Management Journal, 28(13), 1319-1350. http://dx.doi.org/10.1002/smj.640

Thornhill, S. (2006). Knowledge, innovation and firm performance in high-and low-technology regimes. Journal of Business Venturing, 21(5), 687-703. http://dx.doi.org/10.1016/j.jbusvent.2005.06.001

Tidd, J. B., Bessant, J., \& Pavitt, K. (2001). Managing innovation, integrating technological, market and organizational change. New York: John Wiley \& Sons.

Tricker, R. (1994). International corporate governance: Text, readings and cases. New York: Prentice Hall. 
Tsai, F. S. (2005). Composite diversity, social capital, and group knowledge sharing: A case narration. $\begin{array}{lllll}\text { Knowledge Management } \quad \text { Research } & \text { 218-228. }\end{array}$ http://dx.doi.org/10.1057/palgrave.kmrp.8500075

Tsai, W., \& Ghoshal, S. (1998). Social capital and value creation: The role of intrafirm networks. Academy of Management Journal, 41(4), 464-476. http://dx.doi.org/10.2307/257085

Van Buren, M. E. (1999). A yardstick for knowledge management. Training \& Development, 53(5), 41-77.

Vesala, T. (2007). Switching costs and relationship profits in bank lending. Journal of Banking \& Finance, 31(2), 477-493. http://dx.doi.org/10.1016/j.jbankfin.2006.07.010

Von Hippel, E., \& Katz, R. (2002). Shifting innovation to users via Toolkits. Management Science, 48(7), 821-833. http://dx.doi.org/10.1287/mnsc.48.7.821.2817

Wang, C. L., \& Ahmed, P. K. (2007). Dynamic capabilities: A review and research agenda. International Journal of Management Reviews, 9(1), 31-51. http://dx.doi.org/10.1111/j.1468-2370.2007.00201.x

Wang, C. H., \& Hsu, L. C. (2010). The influence of dynamic capability on performance in the high technology industry: The moderating roles of governance and competitive posture. African Journal of Business Management, 4(5), 562-577. Retrieved from http://www.academicjournals.org/article/article1380711969_Wang\%20and\%20Hsu.pdf

Wang, C. H., Hsu, L. C., \& Fang, S. R. (2008). The determinants of internationalization: Evidence from the Taiwan high technology industry. Technological Forecasting and Social Change, 75(9), 1388-1395. http://dx.doi.org/10.1016/j.techfore.2008.03.002

Westerlund, M., \& Svahn, S. (2008). A relationship value perspective of social capital in networks of software $\begin{array}{llll}\text { SMEs. Industrial } & \text { Marketing }\end{array}$ http://dx.doi.org/10.1016/j.indmarman.2008.04.003

Williamson, O. E. (1991). Strategizing, economizing, and economic organization. Strategic Management Journal, 12(8), 75-94. http://dx.doi.org/10.1002/smj.4250121007

Winter, S. G. (2003). Understanding dynamic capability. Strategic Management Journal, 24(10), 991-995. http://dx.doi.org/10.1002/smj.318

Woodruff, R. B. (1997). Customer value: The next source for competitive advantage. Journal of the Academy of Marketing Science, 25(2), 139-153. http://dx.doi.org/10.1007/BF02894350

Workman, J. P., Homburg, C., \& Jensen, O. (2003). Intraorganizational determinants of key account management effectiveness. Journal of the Academy of Marketing Science, 31(1), 3-21. http://dx.doi.org/10.1177/0092070302238599

Zahra, S. A., \& Bogner, W. C. (1999). Technology strategy and software new venture performance: Exploring the moderating effect of the competitive environment. Journal of Business Venturing, 15(2), 135-173. http://dx.doi.org/10.1016/S0883-9026(98)00009-3

\section{Copyrights}

Copyright for this article is retained by the author(s), with first publication rights granted to the journal.

This is an open-access article distributed under the terms and conditions of the Creative Commons Attribution license (http://creativecommons.org/licenses/by/3.0/). 